Discussion Paper No. 618

\author{
DOES A LARGE LOSS OF \\ BANK CAPITAL CAUSE \\ EVER-GREENING OR FLIGHT TO QUALITY?: \\ EVIDENCE FROM JAPAN
}

Wako Watanabe

September 2004

The Institute of Social and Economic Research

Osaka University

6-1 Mihogaoka, Ibaraki, Osaka 567-0047, Japan 


\title{
Does a Large Loss of Bank Capital Cause Ever-greening or Flight to Quality?: Evidence from Japan
}

\author{
Wako Watanabe* \\ Osaka University
}

September 2004

\begin{abstract}
Constructing a strong and unique instrument for bank capital from the empirical observation of Japanese banks' past behavioral changes, we identify the impact of capital adequacy on the allocation of bank lending supply across low quality and high quality borrowers. We find that, in FY 1997, a large loss of capital resulting from the regulator's tougher stance against banks induced banks to rebalance their lending portfolio toward low quality borrowers. Our findings also suggest that the public recapitalization of banks in FY 1998 effectively helped banks abandon the assistance of such zombies.
\end{abstract}

Keywords: ever-greening, flight to quality, bank capital, instrumental variable JEL classification: C21, G21

* I am greatly indebted to Ben Bernanke for his continuous advise, support, and extensive comments. I would also like to thank Han Hong, Takeo Hoshi, Charles Yuji Horioka, Anil K. Kashyap, Miles Kimball, Jean-Phillip Laforte, Guido Lorenzoni, Yoichi Nemoto, Gary Saxonhouse, and two anonymous referees. Finally, I would like to thank seminar participants in the Princeton Macro/International Student Workshop, Bank of Japan, Osaka University, Hitotsubashi University, Kobe University, Keio University, and Tsukuba University for many useful comments and suggestions. Financial support from the Economics Department of Princeton University is gratefully acknowledged. Any possible errors in the following pages are my own.

${ }^{\dagger}$ Address: Institute of Social and Economic Research, Osaka University, 6-1 Mihogaoka, Ibaraki, Osaka, 567-0047 Japan

Phone: 81-6-6879-8566; Fax: 81- 6-6878-2766

E-mail:watanabe@iser.osaka-u.ac.jp 


\section{Introduction}

This paper intends to provide the empirical answer to the question "Did Japanese banks make adjustments of quality of lending supply in response to a large negative capital shock under the BIS risk based capital regulatory framework? If so, how?" It was in FY 1997 that Japanese banks finally recognized a huge amount of non-performing loans under the strong regulatory pressure and that they went through a huge loss of capital. Bank capital, already having been damaged by a series of negative events in the financial crisis that had surfaced since FY 1995, reached the level low enough to bring up the regulatory intervention as a real threat. A bank in response may have reduced the risk exposure by shifting their supply of loans to high quality borrowers. Such a behavior is often referred to as the "flight to quality". The bank may, on the contrary, have kept low quality borrowers alive by supplying more loans to them and thereby prevented NPLs from surfacing on its financial statements. This is a behavior popularly called the "ever-greening" or the "forbearance lending".

The empirical answer to our question has interesting policy implications. If bank loans are directed from low quality borrowers to high quality borrowers, the bank lending channel of monetary policy transmission still plays an important role of propagating the easing effects into productive borrowers, and public recapitalization of banks prevent them from reducing credit supply to high quality borrowers. If the direction of supply of loans is exactly opposite, the policy mix of easing monetary policy and recapitalization leads to the inefficient financial support of unproductive industries and firms. If this is the case, the policymakers should instead consider stimulating lending demand of productive borrower firms. Borrowers, not banks, are the source of problems.

The methodological contribution of this paper is use of the unique identification strategy that exploits the banks' structural behavioral changes in the 1980s under financial liberalization. Banks shifted their lending portfolio toward real estate lending under the bullish expectations on land prices. Entering 1990s, the land price bubble was burst and large portion of real estate lending 
became non-performing. Thus the higher real estate lending share in the late 1980s explains the higher non performing loans (NPLs) and lower bank capital in the late 1990s. Use of the real estate lending share within the bank's loan portfolio in the end of 1980s, which is very strongly correlated with bank capital almost a decade later, as an instrument allows us to identify the lending supply function with the possible demand side capital-borrowing relationship. Loans are disaggregated into loans to the industries where NPLs concentrate (low quality borrowers) and those to the industries where NPLs are minor presence (high quality borrowers) and the redistribution of supply of loans across two groups of borrowers in response to a bank capital shock is examined.

The paper is organized as following. In section 2, the bank's possible behavioral reactions in response to a loss of its own capital are discussed, and the relevant literature is reviewed. In section 3, data and econometric issues are examined. In section 4, empirical results are reported. Section 5 concludes.

\section{Loss of bank capital, flight to quality, credit crunch, and ever-greening}

A loss of bank capital occurred through such various adverse events as the bank's contribution to the liquidation of jusen housing loan companies, the declining bank profitability, and distrust in the banking industry by market participants. $\quad$ It was, however, the regulator's switch to the tougher stance against banks by urging them the very rigorous self-assessment of their assets in FY 1997 that resulted in the unprecedented scale of loss of bank capital. Until then most of NPLs had been left unrecognized and had not appeared on the banks' financial statements. ${ }^{2}$

The RBC regulatory framework requires banks to satisfy the minimum standard for the ratio of

\footnotetext{
${ }^{1}$ Distrust in the Japanese banking industry by market participants surfaced as the Japan premium in 1996 and 1997. In the Eurodollar and Euroyen inter-bank markets, lenders charged Japanese banks higher rates than other international banks. See Peek and Rosengren (2001).

${ }^{2}$ Hoshi and Kashyap (2001) provide the best summary source of chronology of the Japanese financial crisis.
} 
capital to risk weighted assets (riskier assets are assigned to higher weights), the so called RBC ratio. $^{3}$ Lending has been assigned $100 \%$ irrespective of credit risks of each contract (credit worthiness of each borrower). Introduction of the prompt corrective action framework (PCA) in FY 1997, which allows the regulator to intervene into banks with the RBC capital ratio below the regulatory minimum, made failure to achieve the minimum standard particularly costly for banks. ${ }^{4}$

What can a bank do if a large loss of capital brings down the RBC ratio to the level close to the regulatory minimum? Asymmetric information -- involving investors, a bank, and borrowers -makes issuing the new equity costly. ${ }^{5}$ There are, however, potentially three ways for the bank to raise the $\mathrm{RBC}$ ratio without issuing equity. Firstly, if associated costs are negligible, the bank may examine individual lending contracts (or at least individual borrowers), and reduce riskier loans, while holding safer loans. This is the bank's flight to quality in response to a negative capital shock. Secondly, if such costs are prohibitively high, banks may cut supply of loans irrespective of borrowers' credit worthiness. This is credit crunch. Lastly, the bank can be engaged in the so-called ever-greening of borrowers who have great difficulty in servicing their debts. Supply of additional loans to such borrowers not only allows them to fulfill their contractual obligations on the previous debts but also helps the lender bank prevent realizations of NPLs on its financial statements. This paper sheds light on the banks' adjustments on the quality of supply of loans in response to a large loss of their own capital, namely tests the ever-greening hypothesis against the flight to quality

\footnotetext{
3 The franework was agreed in the Basel Accord and took full effect for fiscal year for 1993 in Japan. All banks publicly reported ratios under the Japanese Bankers Association (zenginkyo) criteria. The principle of the regulation is that banks exposed to higher risks should hold more equity capital as a buffer.

${ }^{4}$ The regulatory minimum is the Basel standard of 8 percent for banks that conduct international businesses and 4 percent for those that operate only domestically. It is only major banks that pertained to the PCA in the introductory year of FY 1997. However, other banks must have foreseen the PCA's greater coverage of the banking industry.

${ }^{5}$ See Stein (1998) and Diamond and Rajan (2000) for discussions on the bank's cost of issuing equity due to the asymmetric information.
} 
hypothesis by examining shifts of supply of loans among borrowers with varied financial strength. ${ }^{6}$

The hypotheses have been tested by comparing small business lending with loans to larger firms with various sets of data from both the US and abroad, on the ground that creditors should reduce loans to opaque small firms in times of losses of capital (Bernanke and Lown [1991], Peek and Rosengren [1995], Hancock and Wilcox [1998], Berger, Klapper, and Udell [2001]). The results are not very conclusive. ${ }^{7}$ Since banks as relationship lenders establish long-term relationships with borrowers through rounds of lending contracts, small firms are not necessarily more opaque to banks than larger firms are. ${ }^{8}$ Thus, this traditional approach may be misleading.

A growing number of recent empirical works support ever-greening by Japanese banks. Kobayashi, Saita, and Sekine (2002) present that the growth of loans to highly leveraged firms accelerates. Peek and Rosengren (2004) find that a main bank with a strong relationship with a firm is likely to extend credit to the firm in response to financial deterioration of a firm and a lender itself than a non-relationship lender. ${ }^{9}$

\section{Empirical methodology}

\section{Empirical model}

Consider the following equation.

${ }^{6}$ According to Bernanke and Gertler (1995) and Bernanke, Gertler, and Gilchrist (1998), credit supply to borrowers with higher net worth is greater than to those with lower net worth under the optimal contract, when there is the asymmetric information between the lender and the borrower. The allocation of credit supply is accelerated in the wake of a negative shock to creditors such as tightening monetary policy and a loss of bank capital.

${ }^{7}$ Gertler and Gilchrist [1994], Oliner and Rudebusch [1995, 1996], and Lang and Nakamura [1995] support the banks' flight to quality in response to tightening monetary.

${ }^{8}$ For the empirical evidence of banks as relationship lenders, see Berger and Udell (1995), Petersen and Rajan (1994, 2002), Cole (1998), Degryse and Cayseele (2000) and Berger, Klapper, and Udell (2001).

${ }^{9}$ For the extensive literature review, see Caballero, Hoshi, and Kashyap (2003) and Kobayashi, Saita, and Sekine (2003). 


$$
\Delta \ln L_{i t}^{j}=\alpha_{0}^{j}+\alpha_{1}^{j} \Delta \ln L_{i t-1}^{j}+\beta_{t}^{j}\left\{\frac{K_{i t}}{A_{i t}}-\left(\frac{K_{i}}{A_{i}}\right)^{*}\right\}+\gamma^{j} X_{i}+\varepsilon_{i t}^{j}
$$

The dependent variable $L_{i t}{ }^{j}$ is the lending growth of an individual bank $i$ to the $j$ 'th group of industries at date $t$. Explanatory variables are the lagged dependent variable and the difference between actual and target levels of the capital to asset ratio, $K_{i t} / A_{i t}-\left(K_{i} / A_{i}\right)^{*}$, which we call capital "surplus" ("shortage" if it is negative). ${ }^{10} X_{i}$ is a set of dummy variables that control for the bank's institutional characteristics, CITY, TRUST, and REGIONAL, which indicate a city bank, a trust bank, and a regional bank respectively. Since each group of banks has had the distinct customer base, it is meant to control the lending demand. ${ }^{11} \quad \varepsilon_{i t}^{j}$ is the error term.

As Van den Heuvel (2002) shows, when a bank maximizes the expected sum of future dividend payouts under the Basel regulatory framework, it starts to cut back on its lending supply only when its capital to asset ratio is sufficiently close to but above the regulatory minimum. How earlier the bank acts in response to a loss of capital, which is the buffer to the regulatory minimum for the forward-looking bank, depends on the bank's characteristics such as risk averseness, size and institutional and legal status. ${ }^{12}$ The bank specific target on the capital asset ratio $\left(K_{i} / A_{i}\right)^{*}$ models the point that triggers the bank's action.

\section{Data and sample selection}

The main data source of bank level data is the Nikkei NEEDS bank financials data bank, which

${ }^{10}$ In fact we subtract the regulatory minimum from the RBC ratio in the level specification until FY 1996, since most "international" banks stay above the 8 percent regulatory minimum whereas "domestic" banks stay around their 4 percent regulatory minimum. The distinction between both regulatory types became less obvious after many "international" banks switched their regulatory status to "domestic."

11 Dummy variables are based on the conventional classification of Japanese banks. Besides three used for constructing dummy variables, long-term credit banks does not survive the construction of the analyzed sample, which will be discussed soon, and regional 2 banks are used as the base group.

12 See Hancock and Wilcox (1994) for the discussion 
has become standard for the recent empirical works of Japanese banks. ${ }^{13}$. The data represents a 27 year-long period from FY 1974 to FY 2000. It contains not only balance sheets and income statements of all domestically licensed banks, but also bank loans classified by industry, allowing us comparison of loans supplied to various sectors. ${ }^{14}$

In order to identify the banks' reactions to loss of their own capital with the simultaneous falls in loans and capital by failed banks during the process of liquidation (or clean up of NPLs in preparation for handover to a new management), banks affected by bank failures, liquidated or nationalized banks as well as banks having experienced rescue mergers or acquisitions of failed banks, are dropped from the sample. ${ }^{15}$ As a result total of 126 banks remain in the sample.

\section{Disaggregating lending data into healthy and troubled industries}

Non-performing loans reduce the firm's net worth. Large NPLs suggest that priority of the allocation of a firm's resources is centered at servicing debts and that the firm is deprived of growing opportunities by investing into profitable projects. An industry is labeled as a "troubled" industry if the share of NPLs to the industry within entire existing NPLs exceeds the share of total loans to the industry within entire loans as of the fiscal year end of 2000. "Troubled" industries defined as such are real estate, construction, wholesale and retail, and service. As displayed in Figure 1, they account for three-fourths of total NPLs, while only 46 percent of entire loans are directed to them.

\section{[Insert Figure 1 about here.]}

Testing the "flight to quality" hypothesis against the "ever-greening" hypothesis is conducted

\footnotetext{
13 Ogawa and Kitasaka (2000), Hoshi and Kashyap (2000), Ueda (2000), and Hoshi (2001)

${ }^{14}$ Missing items on recent balance sheets of a few banks are supplemented by their annual reports.

15 Banks having experienced non-rescue mergers are treated as single banks in pre-merger dates by adding values of variables for banks involved in the deals. One long-term credit bank was dropped since detailed lending data for the 1980s are missing. One regional 2 bank founded in the 1990s is also dropped.
} 
by comparing results of estimated bank lending supply functions to "troubled" industries and to the rest ("non-troubled" industries).

\section{$\underline{\text { The capital measure }}$}

The ratio of book capital to total asset (book-based ratio) is used as a capital measure in running regressions of equation (1). There are two other possible candidates, the BIS risk based capital asset ratio and the market-based capital asset ratio that includes unrealized gains (or losses) on holding assets as capital. The book-based ratio is superior for two main reasons. First, the Basel regulatory framework requires banks that at least 50 percent of regulatory capital necessary for their risk-adjusted asset be core (Tier 1) capital, which roughly corresponds to the book capital. Second, by normalizing capital by risk-"unadjusted" asset, we are able to isolate shocks to capital. Normalizing instead by risk-"adjusted" capital would result in the feedback effect from the growth of supply of loans (the dependent variable) to the capital asset ratio through the denominator (of the independent variable). ${ }^{16}$ Besides, banks can control the level of BIS capital by issuing supplemental quasi-capital instruments such as subordinate debts in the wake of loss of core capital, and the Basel regulatory framework does not set the standard for the market-based ratio. ${ }^{17}$

\section{Estimation methodology}

We use the time-series average of each capital asset ratio measure for each bank over the fiscal years of 1992-1994 as a target. The aggregate capital asset ratio of domestically licensed banks stays at a high plateau of around 5 percent since FY 1992 until FY 1994 (Figure 2). It makes sense

\footnotetext{
16 The larger the outstanding loans are, the larger the risk adjusted asset is, and the smaller the risk-adjusted capital asset ratio is since loans are assigned the highest risk factor of 100 percent.

${ }^{17}$ Ito and Sasaki (1998) find that Japanese banks increased subordinate debts in response to their losses on core capital in the early 1990s.
} 
to believe that banks have achieved their targets during this period. Periods before and after the sample period are excluded because 1; the Basel regulatory framework did not take in full effect until FY 1992 and 2; they experienced large losses of bank capital in FY 1995 and in FY $1997{ }^{18}$

[Insert Figure 2 about here.]

The target constructed this way varies across banks but is time invariant. Figure 3 shows that capital shocks are aggregate rather than idiosyncratic in nature and influence individual banks' capital positions in a synchronized manner. In FY 1997 all the banks were either short of or just achieved their targets. Importantly, all of large banks were severely short of their targets. In FY 1998, in turn, many of banks drummed up their capital and had achieved their targets. By FY 1999, most of banks restored their targets. The time variant but cross-sectionally invariant reaction coefficient $\beta_{t}^{j}$ is meant to capture the banks' reaction to such aggregate shocks.

[Insert Figure 3 about here.]

The target may change over time as the regulatory and economic environments change. The most important of economic factors to influence the bank's target are arguably interest rates, which had stayed low and barely changed in the late 1990s. Use of information from the period of shocks to bank capital in estimating the time variant target is problematic since the target estimated as such does not isolate a change in the target from a change in the actual capital position. ${ }^{19}$ Ignoring time-series changes in targets does not bias results on the direction of the banks' distributive adjustments of lending supply much unless changes exhibit great idiosyncrasy. ${ }^{20}$ Supply cut of

18 The Basel Accord agreed in 1988 encouraged banks to accumulate adequate capital by the full implementation.

19 Alternatively one may estimate the relationship between the banks' capital ratio and their characteristics (size, regulatory and institutional dummy variables from pre- crisis and post Basel years (1992-1994) and then compute fitted values for out of sample crisis years (1995-2000). This would accommodate the banks' switch in regulatory status from higher to lower minimum capital requirement if they actually do so over FY 1995- FY 2000. Unfortunately the estimated relationship over 1992-1994 is very inaccurately estimated, and quite a number of banks have negative values for their targets estimated this way during FY 1997- FY 1999.

${ }^{20}$ A bank wide change in the banks' targets, common to all the banks, simply changes capital "surpluses" of all the 
lending to both "troubled" and "non-troubled" industries induced by shortfall to targets is underestimated by roughly an equal degree.

We estimate equation (1) with a yearly panel of banks by interacting time dummies with explanatory variables to leave coefficients, including one on capital "surplus" $K_{i t} / A_{i t}-\left(K_{i} / A_{i}\right)^{*}$, time-variant. $^{21}$ We could restrict some of coefficients to be time invariant if they seem to be stable over time. $^{22}$

\section{$\underline{\text { Simultaneity and identification }}$}

The OLS estimator of the coefficient on the capital "surplus" measure $\beta$ in equation (1) may capture not only the needed banks' behavioral responses but also the potential demand side relationship. If the economic condition worsens, firms adjust their investments downward, which in turn results in declining borrowing demand. On the other hand, the firms' sluggish sales performances may prevent them from earning revenues high enough to service their debts on time. Thus, their existing loans become non-performing, which reduces the lender banks' capital. Similarly in an economic upturn, borrowing demand soars, while the higher profits of the banks are

banks by an equal degree.

${ }^{21}$ Indeed resulting point estimates are numerically equivalent to those from separate cross sectional regressions.

${ }^{22}$ It is possible to interpret $\beta_{t}^{j}\left(K_{i} / A_{i}\right)^{*}$ obtained through expanding the bracket on the right hand side of equation (1) as the time-variant response of bank lending to the observed bank specific fixed effect. Theoretically, one could model the time-variant response of bank lending supply to the standard unobservable fixed effect, which is incorporated in the regression equation as a time dummy, and identify the time-variant response and the fixed effect. One could, then, test whether the "restricted" model with the estimated target outperforms the "unrestricted" model with the unobserved fixed effect by using, say, the log likelihood principle. To make two regression results comparable by the standard test statistic, the set of instruments has to be shared by both models. Since bank dummies have to be included in the "unrestricted" model to ensure the high dimension of the set of instruments, so do in the original model. The attempted inclusion of bank dummies as instruments in the "restricted" model resulted in implausible estimates. Developing a new testing method is a good agenda in the future research. 
added to their equity capital.

In order to identify the bank lending supply function from the balance sheet data, we need a valid instrument that is independent of the error term $\varepsilon_{i t}$ and strongly correlated to the capital asset ratio, $K_{i t} / A_{i t}$. The bank's share of real estate lending within its lending portfolio in FY 1989, which we call REAL89, is a unique variable that satisfies conditions to be a good instrument. It effectively overcomes the drawback of the classical approach in the literature to use lagged "predetermined" variables that lack an economic account of bank capital and whose correlation with bank capital is not guaranteed. ${ }^{23}$

Ueda (2000) and Hoshi (2001) find that the bank's portfolio tilt toward the real estate industry in the 1980s best accounts for the size of the NPLs of that bank in the late 1990s. In response to the loss of long-standing large keiretsu firms, which were beneficiaries of the financial liberalization (deregulation) and turned to financial markets to raise needed funds, banks made the structural reorganization of their customers to weigh more on the real estate companies, expecting that land prices would never fall. ${ }^{24}$ As the land price bubble busted, many real estate lending became bad loans, and later were recognized as NPLs on the bank's financial statements in the late 1990s and ate capital.

The banks' behavioral responses to the deregulation in the mid-1980s are exogenous to the demand-supply system of bank lending in the 1990s, and REAL89 is independent of the error term in the lending supply function (1). The instrumental variable regression with REAL89 thus picks up the bank's response to a loss of bank capital due to its structural behavioral change in the 1980s and isolate out the effect of concurrent business cycles (demand side). ${ }^{25}$ REAL89 is strongly

${ }^{23}$ See Peek and Rosengren (1995 a) and Ogawa and Kitasaka (2000). Peek and Rosengren (1995 a) adds the current change in equity capital as one of instruments to lagged variables.

${ }^{24}$ For more on the Japanese financial liberalization, see Hoshi and Kashyap (2000)

${ }^{25}$ REAL89 is meant to capture large falls in land prices due to the bubble burst that predominantly preceded a large loss of bank capital in the late 1990s. A large loss of capital, though stemming from falls in land prices, had 
negatively correlated to capital "surpluses" since FY 1995 (Table 1).

[Insert Table 1 about here.]

\section{Results}

\section{$\underline{\text { Regression results }}$}

Table 2 shows the estimates of the coefficient on the contemporaneous capital "surplus", $\beta$, from the 2SLS regression of equation (1) with the panel of banks since FY 1995 through FY $2000{ }^{26}$ The first raw presents the results on the bank lending supply to "troubled" industries not closely related to the real estate industry: industries included are wholesale and retail, and service. The second raw labeled "non-troubled (2)" presents the results on lending supply to the healthy non-manufacturing industries little burdened with NPLs (agriculture, mining, financial and insurance, transportation and communications, and utility). The third raw labeled "non-troubled (3)" presents the results on lending to healthy non-manufacturing industries excluding the financial and insurance industry (agriculture, mining, transportation and communications, and utility). ${ }^{27}$

not occurred until the regulator urged banks to write off NPLs in FY 1997. Changes in land prices in the late 1990s are minor relative to the bust of land price bubble that had occurred earlier. For instance, the land price in Tokyo fell 38 percent over a five-year period from FY 1991 to FY 1995, whereas it fell only 9 percent over a three-year period from FY 1997 to FY 1999. Thus changes in land prices do not cause serious problems in interpreting the results of instrumental variable regressions in different years. One way to take into account changes in land prices in the late 1990s are to use the product of REAL89 and the contemporaneous land price as an instrument. REAL89 multiplied by the land price, however, loses a strong explanation power of bank capital in the sample.

26 The regulator's official notice on the rigorous assessment framework of bank assets was published on March 5th, 1997, about a year before the fiscal year end of 1997. So banks knew a year in advance that a large loss of capital was inevitable at the fiscal year end of 1997. The regression equations with the lagged capital asset ratio were also examined. When the contemporaneous ratio is significant and positive, so is generally the coefficient on the lagged ratio. As the constructed capital "surplus" is a stock of capital less the time invariant target, it is strongly sereally correlated. In fact regressions with both lagged and contemporaneous ratios wash away the statistical significance of coefficients on the lagged ratio. Besides an overidentification test rejects the null hypothesis at $10 \%$ level for the lag specification for troubled lending in fiscal years 1997.

${ }^{27}$ Some non-banks are said to have been engaged in intensive real estate related lending. Though presence of 
[Insert Table 2 about here.]

The estimated coefficient is positive and weakly significant for "troubled" industries and is not statistically significant for lending supply to "non-troubled" industries in FY 1996. In FY 1997 the estimated coefficient is positive and statistically significant for lending supply to both groups of industries, though the point estimate is substantially larger for "non-troubled" industries than for "troubled" industries. ${ }^{28}$ The coefficient is estimated larger for "non-troubled" industries than for "troubled" industries in FY 1998, though it is not significant for "non-troubled" industries when they exclude the financial and insurance industry (FII). ${ }^{29}$

\section{Aggregate impact of bank capital}

Table 3 compares actual aggregate growth rates of loans to "troubled" industries and to "non-troubled" industries. ${ }^{30}$ The fall in loans to "non-troubled" industries is larger than the fall in loans to "troubled" industries in FY 1997, 1998, and 2000. In FY 1999 loans to "non-troubled" industries grew while loans to "troubled" industries fell. ${ }^{31}$

NPLs to the industry is not outstanding from the data, we present the results on the healthy non-manufacturing industries excluding the financial and insurance industry to check robustness of the results.

28 The OLS estimator provides statistically significant but substantially smaller point estimates of coefficients than does the 2SLS estimator in fiscal years 1996 and 1997 and insignificant estimates in FY 1998. (Results are not shown.)

${ }^{29}$ Regressions that take into account time effects (time-variant constant) and the time-variant coefficient on capital "surplus" but that keep other coefficients unchanged over time result in qualitatively similar results. The LR tests do not reject such restrictions on coefficients. (Results are not shown.)

30 The data are constructed from the micro data of banks included in the sample of the cross sectional regressions, thereby make them comparable to the aggregate supply side effects of bank capital on lending that are computed from the estimation of equation (1).

31 Clean up of loans to jusen companies is the most likely cause of a positive growth of loans to "non-troubled" industries including the financial and insurance industry and a negative growth of loans to "non-troubled" industries excluding it in FY 1995 and FY 1996. 
[Insert Table 3 here.]

Table 4 compares estimated aggregate growth rates of lending supply to "troubled" industries and to "non-troubled" industries induced by the banks' capital positions. Each entry aggregates the third term in (1) $\beta_{t}^{j}\left\{K_{i t} / A_{i t}-\left(K_{i} / A_{i}\right)^{*}\right\}$. The corresponding point estimate from Table 3 is used for $\beta_{t}^{j}$ and the asset size is used as a weight. The number measures the aggregate impact of the banks' capital positions on bank lending supply in each year.

The actual capital asset ratio is short of the target on average (aggregate capital "shortage") in fiscal years for 1995, 1996, and 1997, and the actual ratio exceeds the target (aggregate capital "surplus") afterward. ${ }^{32}$ Therefore, the greater entry for "troubled" industries ( -4.7 percent) than for "non-troubled" industries (-8.5 percent if they include FII, and -7.4 percent if they exclude it.) in FY 1997 strongly suggests the banks' industry-wide ever-greening in response to a large loss of capital. Slightly larger entries for "non-troubled" industries than for "troubled" industries in the previous year (FY 1996) could support the banks' flight to quality. Larger entries for "non-troubled" industries in FY 1998 imply the positive allocative effect of the large public capital injection. Compared with Table 3, it is only in FY 1997 that the distribution of loan growth across "troubled" and "non-troubled" industries is strongly attributable to the banks' capital positions.

[Insert Table 4 about here.]

\section{Testing reallocation of lending portfolio}

We attempt the formal statistical test to compare lending supply to "troubled" industries with that to "non-troubled" industries. The regression equation used is obtained by subtracting the equation (1) for "non-troubled" industries $(i=n t)$ from that for "troubled" industries $(i=t r)$, and is estimated by the 2SLS with a set of instrumental variables employed being a union of sets of

\footnotetext{
32 A sign of the aggregated capital "surplus" coincides with the sign of the entry in the first column of Table 4 because as shown in the second column of Table 2, the coefficient on the contemporaneous book-based capital asset ratio is positive in all fiscal years since FY 1995.
} 
instruments used in running regressions of equation (1) for both "troubled" and "non-troubled" sectors. REAL89 remains to play a key role as an identifier.

$\Delta \ln L_{i t}^{t r}-\Delta \ln L_{i t}^{n t}=\left(\alpha_{0}^{t r}-\alpha_{0}^{n t}\right)+\alpha_{1}^{t r} \Delta \ln L_{i t-1}^{t r}-\alpha_{1}^{n t} \Delta \ln L_{i t-1}^{n t}+\left(\beta^{t r}-\beta^{n t}\right)\left[\frac{K_{i t}}{A_{i t}}-\left(\frac{K_{i}}{A_{i}}\right)^{t \text { arget }}\right]+\left(\gamma^{t r}-\gamma^{n t}\right) X_{i}+\left(\varepsilon_{i t}^{t r}-\varepsilon_{i t}^{n t}\right)(2)$

Though statistically insignificant, the point estimate is positive $\left(\beta^{t r}>\beta^{n t}\right)$ in FY 1996 and negative $\left(\beta^{t r}<\beta^{n t}\right)$ in FY 1997 when banks did not achieve their targets as an industry (years of the industry wide capital loss), suggesting the portfolio reorganization toward "non-troubled industries" (flight to quality) in FY 1996 and toward "troubled" industries (ever-greening) in FY 1997. In FY 1998, a year of capital surge, the coefficient is significant and negative when "non-troubled" industries include FII. In FY 1999, in turn, the coefficient is significant and positive when "non-troubled" industries exclude FII. This result is due to the negative and insignificant coefficient for "non-troubled" industries and the positive and insignificant coefficient for "troubled" industries in FY 1999 on Table 2.

High "partial squared correlation coefficients", developed by Shea (1997) to test the strength of the set of instruments employed to explain a capital "surplus", build further confidence in employed instrumental variables (Table 5-2). The complete estimation results of equation (2) are presented in Tables 5-3 ("non-troubled" industries include FII) and 5-4 ("non-troubled" industries exclude FII). ${ }^{33}$ [Insert Tables 5-1, 5-2, 5-3 and 5-4 about here.]

\section{$\underline{\text { Robustness check }}$}

In order to check on the robustness of our position, we replicate the regressions of equation (1) (Table 6-1), the actual growth rates of loans (Table 6-2), the estimated contribution of capital

\footnotetext{
33 Regressions that take into account time effects (time-variant constant) and the time-variant coefficient on capital "surplus" but that keep other coefficients unchanged over time result in very high standard errors for coefficients. None of them is statistically significant at 10 percent level though the LR tests do not reject such restrictions on coefficients. (Results are not shown.)
} 
"surplus" to the distribution of supply of bank loans based on regression results in Table 6-1 (Table 6-3), and the regression results of equation (2) (Table 6-4) with subgroups of banks. Groups investigated are regional banks registered as "domestic" as of the fiscal year end of 2000 and

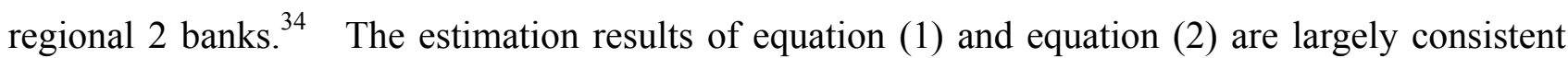
with findings with all banks in the constructed sample until FY 1997. Regional and regional 2 banks continue to be slightly short of capital and seem to ever-green "troubled" borrowers in FY 1998.

[Insert Tables 6-1, 6-2, 6-3 and 6-4 about here.]

\section{Interpretation of empirical results}

The estimated contraction of loan supply to healthy non-manufacturing industries by 7 to 9 percent in FY 1997 induced by undercapitalization of banks demonstrates that the large loss of capital primarily due to the regulator's tougher stance against banks to request more rigorous assessment of their assets caused a credit crunch. More interestingly, banks did not reduce lending supply to unhealthy industries as much as to healthy industries, implying that they ever-greened "troubled" borrowers. ${ }^{35}$ A large loss of capital must have attracted banks to the short eye-sighted accounting solution to drum up the capital to asset ratio. Indeed, the results for FY 1996 are suggestive of the opposite, the portfolio shift toward healthy industries in response to a minor capital loss, flight to quality. Results in later years when banks recovered their targets are not conclusive. The initial large positive capital shock primarily due to public capital infusion into large banks in FY 1998 seems to have assisted these banks in rebalancing their lending portfolio toward healthy

\footnotetext{
3414 regional banks that register as international banks that pertain to the higher minimum capital standard are excluded from the regional bank sub-sample. It serves to test our hypotheses with the very homogeneous sub-sample. All regional 2 banks are registered as domestic banks that are subject to the lower standard.

35 Since there are a greater number of write offs of NPLs in "troubled" industries and disposal of NPLs reduces both loans and capital equally, the disparity in new lending between "troubled" and "healthy" industries must be even more pronounced.
} 
industries and thus had an industry wide impact of improving the quality of lending supply. ${ }^{36}$

\section{Conclusion}

In this paper we estimated the bank lending supply function consistent with the dynamic optimization of the bank regulated by the Basel framework using a powerful identification strategy with a unique instrument. We found that a large loss of bank capital caused by the regulator's tougher policy against banks in FY 1997 not only caused the contraction of bank lending supply (credit crunch), but also were likely to cause the banks' reallocation of lending supply to unhealthy industries with higher concentration of non-performing loans (ever-greening). It casts a sharp contrast with the same banks in the previous year, little short of their targets, that indeed weighed more on the healthier industries. Our findings also imply that public bail out of banks in FY 1998 helped banks escape from further quantitative and qualitative deterioration of lending supply.

\footnotetext{
${ }^{36}$ Public funds injected into the banking system amounted to 58,090 million yen. Funds were selectively supplied to larger banks, most of which were severely undercapitalized at the time of action, thereby were effective to restore the aggregate lending growth in the highly concentrated Japanese banking industry.
} 


\section{References}

Bank of Japan, 2001. Zenkoku ginkou no heisei 12 nendo kessan to keieijou no kadai (Settlements of Accounting of Japanese Banks and Their Managerial Tasks in the Fiscal Year 2000).

Berger, Allen N., Leora F. Klapper and Gregory F. Udell, 2001. The Ability of Banks to Lend to Informationally Opaque Small Businesses. Journal of Banking and Finance, 25 (12), 2127—67.

Berger, Allen N. and Gregory Udell, 1995. Relationship Lending and Lines of Credit in Small Business Finance. Journal of Business, 68 (3), 351-381.

Bernanke, Ben S. and Mark Gertler, 1995. Inside the Black Box: the Credit Channel of Monetary Policy Transmission. Journal of Economic Perspective, 9(4), 27-48.

Bernanke, Ben S., Mark Gertler, and Simon Gilchrist, 1998. The Financial Accelerator and the Flight to Quality. Review of Economics and Statistics, 78 (1), 1-15.

Bernanke, Ben S. and Cara S. Lown, 1991. The Credit Crunch. Brookings Papers on Economic Activity, 1991 (2), 205-39.

Caballero, Ricardo J., Takeo Hoshi, and Anil K. Kashyap, 2003. Zombie Lending and Depressed Restructuring in Japan. mimeo, Graduate School of Business, University of Chicago.

Cole Rebel A. The Importance of Relationships to the Availability of Credit. Journal of Banking and Finance, 22, 959-977.

Diamond, Douglas W. and Raghuram G. Rajan, 2000. A Theory of Bank Capital. Journal of Finance, $55(6), 2431-65$.

Degryse, Hans and Patrick Van Cayseele, 2000. Relationship Lending within a Bank-Based System: Evidence from European Small Business Data. Journal of Financial Intermediation, 23 (9), 90-109.

Gertler, Mark and Simon Gilchrist, 1994. Monetary Policy, Business Cycles, and the Behavior of Small Manufacturing Firms. Quarterly Journal of Economics 109 (2), 309-340.

Hancock, Diana and James A. Wilcox, 1994. Bank Capital, Loan Deliquencies, and Real Estate Lending. Journal of Housing Economics 3 (1), 31-50. 
Hancock, Diana and James A. Wilcox, 1998. The "Credit Crunch" and the Availability of Credit to Small Business. Journal of Banking and Finance 22 (6-8), 983-1014.

Hoshi, Takeo, 2001. What Happened to Japanese Banks? Monetary and Economic Studies February, $1-29$.

Hoshi, Takeo and Anil K. Kashyap, 1999. The Japanese Banking Crisis: Where Did It Come From and How Will It End? NBER Macroeconomic Annual 1999. edited by Ben S. Bernanke and Julio J. Rotemberg.

Hoshi, Takeo and Anil K. Kashyap, 2001. Corporate Financing and Governance in Japan. the MIT Press.

Kobayashi, Keiichiro, Yumi Saita, and Toshitaka Sekine, 2002. Forbearance Lending: A Case for Japanese Firms. Bank of Japan, Research and Statistics Department Working Paper 02-2.

Lang, William W. and Leonard I. Nakamura, 1995. Flight to Quality in Banking and Economic Activity. Journal of Monetary Economics 36, 145-164.

Ogawa, Kazuo and Shin-Ichi Kitasaka, 2000. Bank Lending in Japan: Its Determinants and Macroeconomic Implications. Crisis and Change in the Japanese Financial System. edited by Takeo Hoshi and Hugh Patrick.

Oliner, Stephen D. and Glenn Rudebusch (1995), "Is There a Bank Credit Channel for Monetary Policy? ”, Economic Review, 1995 (2), Federal Reserve Bank of San Francisco.

Oliner, Stephen D. and Glenn Rudebusch, 1996. Monetary Policy and Credit Conditions: Evidence from the Composition of External Finance: Comment. American Economic Review 86 (1), $300-309$.

Petersen, Mitchell A. and Raghuram G. Rajan, 1994. The Benefits of Lending Relationships: Evidence from Small Business Data. Journal of Finance, 49 (1), 3-37.

Petersen, Mitchell A. and Raghuram G. Rajan, 2002. Does Distance Still Matter? The Information Revolution in Small Business Lending. Journal of Finance, 57 (6), 2533 -69. 
Peek, Joe and Eric S. Rosengren, 1995 a. Bank Regulatory Agreements in New England. New England Economic Review, May/June, Federal Reserve Bank of Boston.

Peek, Joe and Eric S. Rosengren, 1997. The International Transmission of Financial Shocks: The Case of Japan. American Economic Review, 87 (4), 495-505.

Peek, Joe and Eric S. Rosengren, 1997. Determinants of the Japan Premium: Actions Speak Louder Than Words. Journal of International Economics, 53 (2), 283-305.

Peek, Joe and Eric S. Rosengren, 2004. Corporate Affiliations and (Mis)Allocation of Credit. forthcoming, Journal of Financial Economics.

Shea, John, 1997. Instrument Relevance in Multivariate Linear Models: A Simple Measure. Review of Economics and Statistics 79 (2), 348-352.

Stein, Jeremy C., 1998. An Adverse-Selection Model of Bank Asset and Liability Management with Implications for the Transmission of Monetary Policy. RAND Journal of Economics 29, 466 — 86.

Ueda, Kazuo, 2000. Causes of Japan's Banking Problems in the 1990s. Crisis and Change in the Japanese Financial System. edited by Takeo Hoshi and Hugh Patrick.

Van den Heuvel, 2002. The Bank Capital Channel of Monetary Policy. mimeo, the Wharton School, University of Pennsylvania

Woo, David, 1999. In Search for "Capital Crunch": Supply Factors Behind the Credit Slowdown in Japan. IMF Working Paper 99/3. 
Figure 1. Non-performing loans and total loans by industry

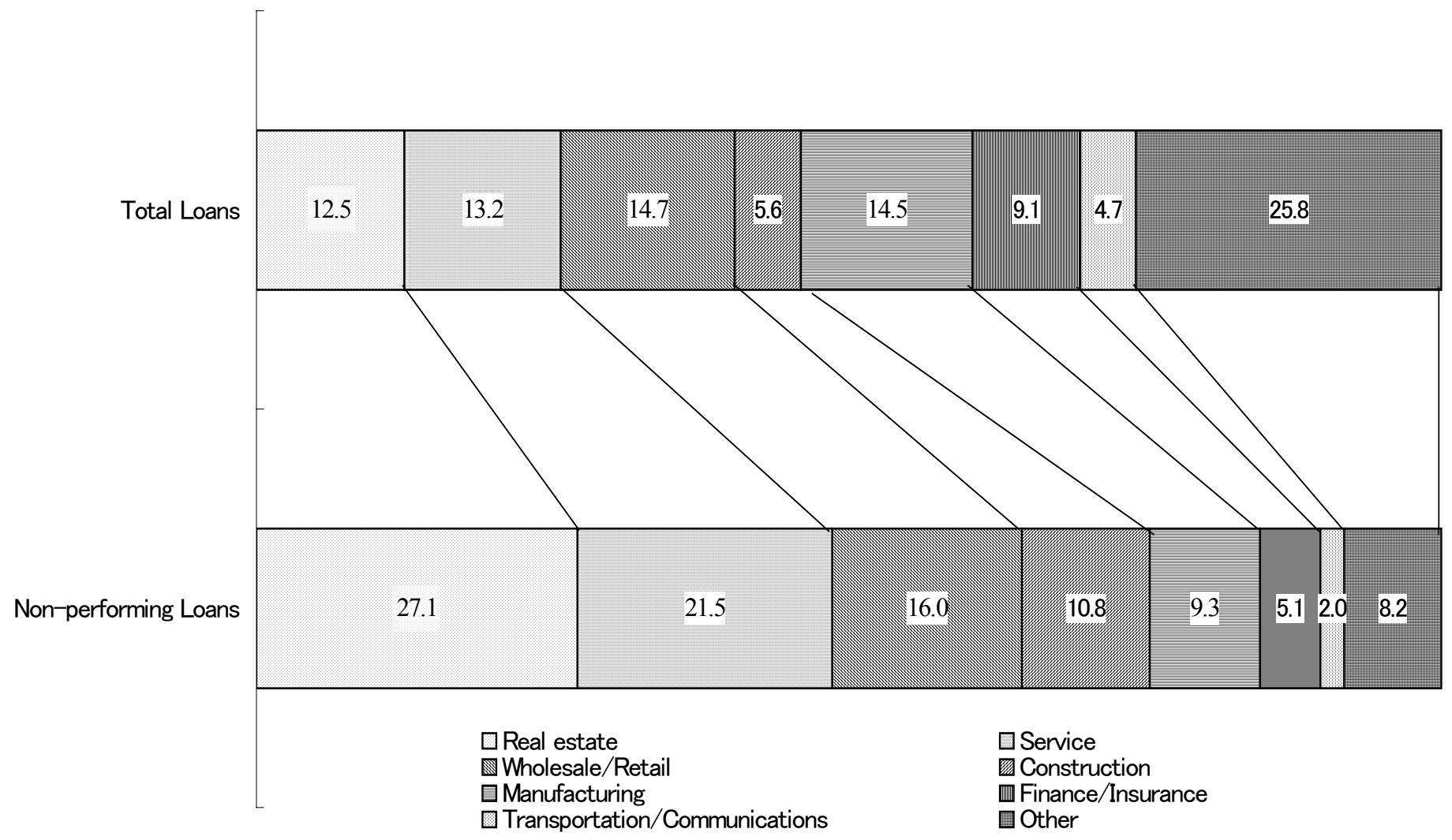

Source: the BOJ (2001)

Figure 2. Domestic loan growth and capital asset ratio of domestically licensed

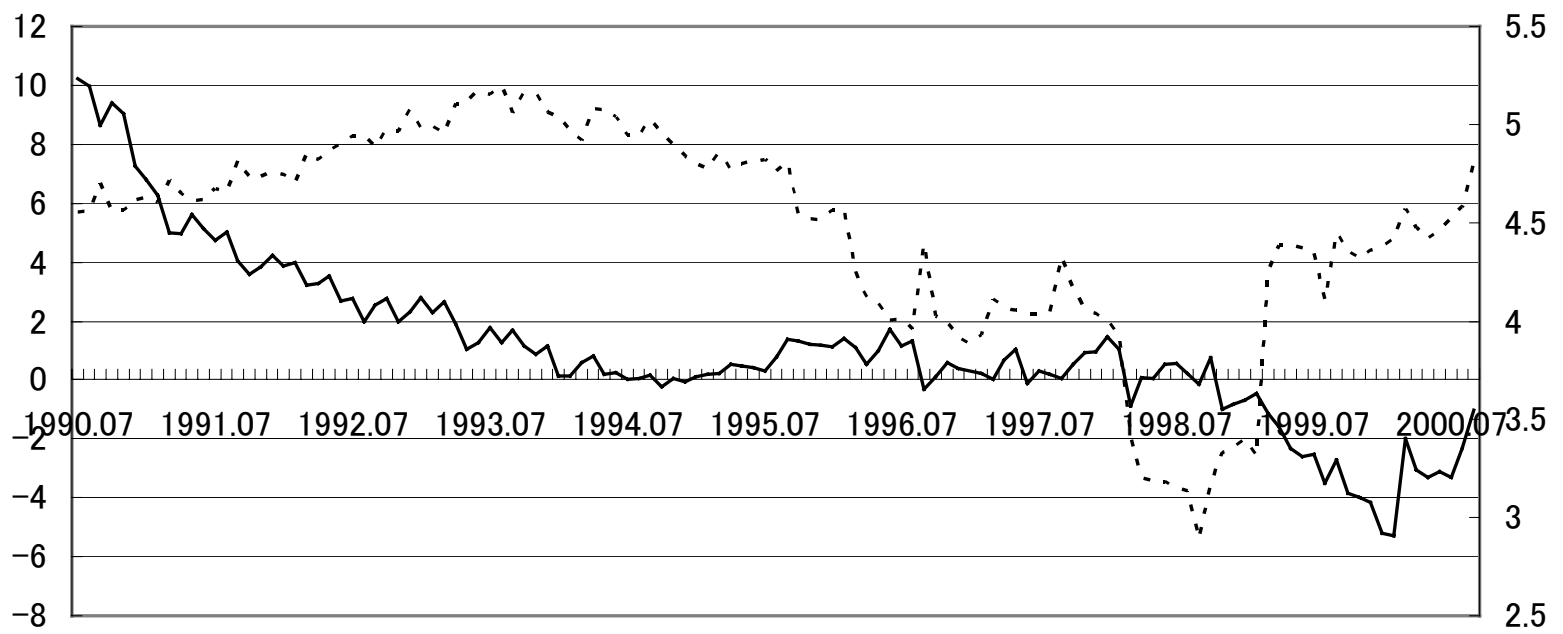

— Lending growth $\ldots$... Capital asset ratio 
Figure 3 Target and actual capital asset ratios

FY 1997

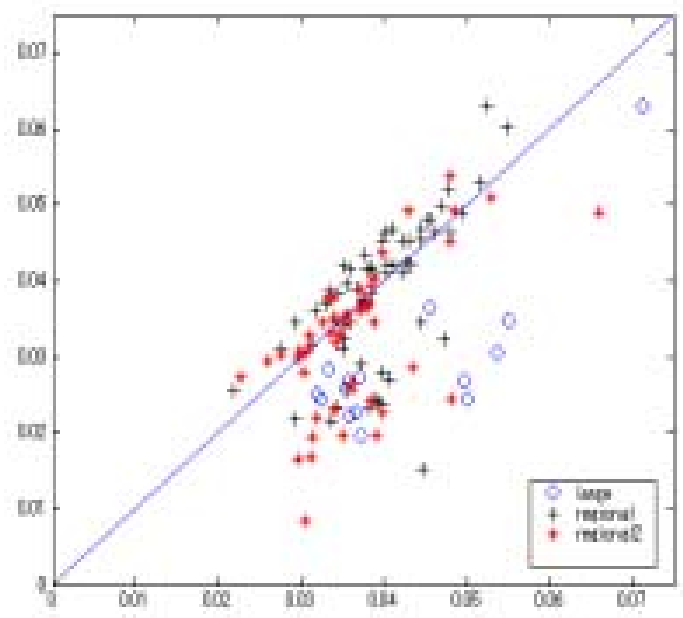

FY 1998

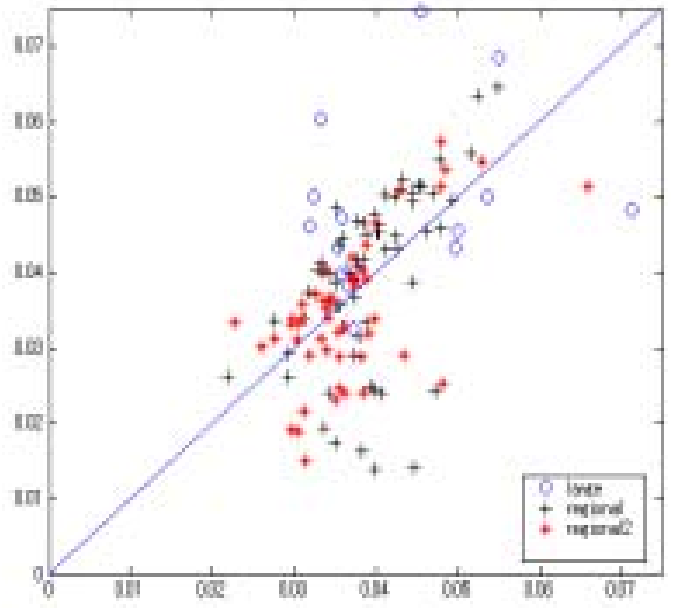

FY 1999

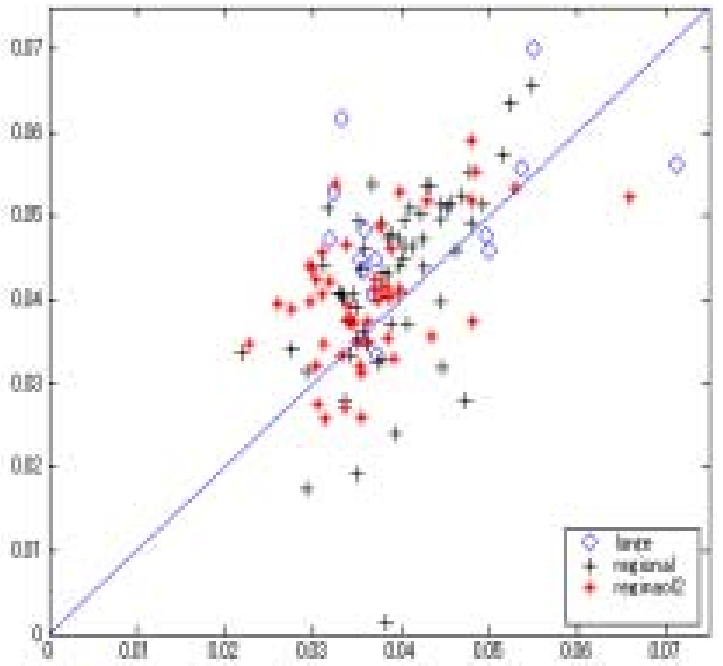

Note: The vertical axis represents the actual capital to asset ratio, and the horizontal axis represents the target ratio. Thus, banks above the 45-degree line are in shortage of actual capital relative to its target, whereas those below the 45-degree line are in surplus of actual capital relative to its target.

Blue circles, black crosses, and red crosses are large banks, regional banks, and regional 2 banks, respectively. 
Table 1 Correlation coefficients of REAL89 and capital "surplus" measures

\begin{tabular}{lllllll}
\hline & 1995 & 1996 & 1997 & 1998 & 1999 & 2000 \\
\hline \hline CAPR & -0.4607 & -0.2767 & -0.5345 & -0.3443 & -0.3214 & -0.4358 \\
\hline
\end{tabular}

Table 2 Year by year coefficients on capital "surplus" measures for loan supply to troubled and non-troubled industries, all 126 banks

\begin{tabular}{|c|c|c|c|c|c|c|}
\hline Group of industries & 1995 & 1996 & 1997 & 1998 & 1999 & 2000 \\
\hline Troubled (1) & $\begin{array}{l}3.3626 \\
(1.2284)\end{array}$ & $\begin{array}{l}2.5416^{*} \\
(1.6936)\end{array}$ & $\begin{array}{c}4.9944^{* * *} \\
(4.1249)\end{array}$ & $\begin{array}{l}2.5271^{*} \\
(1.8360)\end{array}$ & $\begin{array}{l}1.1473 \\
\quad(0.9917)\end{array}$ & $\begin{array}{l}1.3214^{*} \\
\quad(1.9003)\end{array}$ \\
\hline Non- troubled (2) & $\begin{array}{l}3.5128 \\
\quad(0.3291)\end{array}$ & $\begin{array}{l}-2.0894 \\
(-0.3604)\end{array}$ & $\begin{array}{r}9.1686^{* * *} \\
(2.9483)\end{array}$ & $\begin{array}{c}9.6862^{* *} \\
(2.6077)\end{array}$ & $\begin{array}{l}-2.7237 \\
(-0.7951)\end{array}$ & $\begin{array}{c}4.4350^{* *} \\
(2.6075)\end{array}$ \\
\hline Non- troubled (3) & $\begin{array}{r}3.6581 \\
(0.5480)\end{array}$ & $\begin{array}{r}2.1016 \\
(0.2800) \\
\end{array}$ & $\begin{array}{r}7.9786^{* *} \\
(2.3815)\end{array}$ & $\begin{array}{l}4.0622 \\
\quad(0.9929) \\
\end{array}$ & $\begin{array}{r}-4.9156 \\
(-1.5066)\end{array}$ & $\begin{array}{l}0.9873 \\
\quad(0.4845)\end{array}$ \\
\hline
\end{tabular}

Note: $* * *$ shows $1 \%, * *, 5 \%$, and $*, 10 \%$, respectively.

The financial and insurance industry is included into the "non-troubled" industries in the first row and is excluded in the second row.

Table 3 Aggregate lending growths to troubled and non-troubled industries

\begin{tabular}{llrrrrrr}
\hline & 1995 & 1996 & 1997 & 1998 & 1999 & 2000 \\
\hline \hline \multirow{3}{*}{ All banks } & Troubled (1) & -0.43 & -1.51 & -2.12 & -2.61 & -2.98 & -2.56 \\
& Non- troubled (2) & -1.10 & -4.65 & -3.92 & -5.41 & 4.08 & -5.00 \\
& Non-troubled (3) & 3.24 & 0.79 & -2.56 & -3.95 & 2.13 & -3.57 \\
\hline
\end{tabular}

Note: The financial and insurance industry is included into the "non-troubled" industries in the first row and is excluded in the second row.

Table 4 Aggregate capital shocks to bank lending supply to troubled and non-troubled industries, all 126 banks

\begin{tabular}{lccllll}
\hline & 1995 & 1996 & 1997 & 1998 & 1999 & 2000 \\
\hline \hline Troubled (1) & -1.61 & $-1.06^{*}$ & $-4.65^{* * *}$ & $1.00^{*}$ & 0.78 & $0.68^{*}$ \\
Non- troubled (2) & -1.68 & 0.87 & $-8.54^{* * *}$ & $3.82^{* *}$ & -1.85 & $2.29^{* *}$ \\
Non- troubled (3) & -1.75 & -0.88 & $-7.43^{* *}$ & 1.60 & -3.34 & 0.51 \\
\hline
\end{tabular}

Note: $* * *$ shows $1 \%, * *, 5 \%$, and $*, 10 \%$, respectively.

The financial and insurance industry is included into the "non-troubled" industries in the first row and is excluded in the second row. 
Table 5-1 Year by year coefficients on capital "surplus" measures in equation (2), all 126 banks

\begin{tabular}{|c|c|c|c|c|c|c|}
\hline & 1995 & 1996 & 1997 & 1998 & 1999 & 2000 \\
\hline $\begin{array}{l}\text { Non-troubled includes } \\
\text { financial and insurance }\end{array}$ & $\begin{array}{l}4.2215 \\
(0.3807)\end{array}$ & $\begin{array}{l}6.4602 \\
(1.2795)\end{array}$ & $\begin{array}{r}-4.3578 \\
(-1.3532)\end{array}$ & $\begin{array}{r}-7.7444^{* *} \\
(-2.1423)\end{array}$ & $\begin{array}{l}3.1321 \\
(1.0909)\end{array}$ & $\begin{array}{r}-2.1843 \\
(-1.1048)\end{array}$ \\
\hline $\begin{array}{l}\text { Non-troubled excludes } \\
\text { financial and insurance }\end{array}$ & $\begin{array}{l}0.6162 \\
(0.0545)\end{array}$ & $\begin{array}{r}4.1433 \\
(0.6964)\end{array}$ & $\begin{array}{r}-3.4977 \\
(-1.6156)\end{array}$ & $\begin{array}{r}-1.4617 \\
(-0.5053)\end{array}$ & $\begin{array}{l}6.9203^{* *} \\
(2.5379)\end{array}$ & $\begin{array}{l}2.5125 \\
(0.5701) \\
\end{array}$ \\
\hline
\end{tabular}

Note: The financial and insurance industry is included into the "non-troubled" industries in the first row and is excluded in the second row.

$* * *$ shows $1 \%, * *, 5 \%$, and $*, 10 \%$, respectively.

The Hansen's (1982) overidentification test does not reject the null hypothesis that instruments are uncorrelated with a set of explanatory variables for any regression at least at $10 \%$ level. (Results are not shown.)

Table 5-2 Partial squared correlation coefficients

\begin{tabular}{lcccccc}
\hline & 1995 & 1996 & 1997 & 1998 & 1999 & 2000 \\
\hline \hline $\begin{array}{l}\text { Non-troubled includes } \\
\text { financial and insurance }\end{array}$ & 0.0916 & 0.1305 & 0.1734 & 0.0960 & 0.1495 & 0.2403 \\
$\begin{array}{l}\text { Non-troubled excludes } \\
\text { financial and insurance }\end{array}$ & 0.1090 & 0.1267 & 0.2039 & 0.1025 & 0.1592 & 0.2167 \\
\hline
\end{tabular}

Table 5-3 Regression results of equation (2), "non-troubled" industries include the financial and insurance industry

\begin{tabular}{|c|c|c|c|c|c|c|}
\hline & 1995 & 1996 & 1997 & 1998 & 1999 & 2000 \\
\hline Constant & $\begin{array}{l}0.0027 \\
(0.1204)\end{array}$ & $\begin{array}{l}-0.0195 \\
\quad(-0.9187)\end{array}$ & $\begin{array}{r}-0.0366 \\
\quad(-1.5142)\end{array}$ & $\begin{array}{r}-0.0523^{* *} \\
(-2.3256)\end{array}$ & $\begin{array}{l}-0.0284 \\
(-1.2246)\end{array}$ & $\begin{array}{l}-0.0218 \\
(-0.8286)\end{array}$ \\
\hline $\begin{array}{l}\text { Lagged growth of } \\
\text { "troubled" lending }\end{array}$ & $\begin{array}{l}-0.1793 \\
(-0.4678)\end{array}$ & $\begin{array}{l}0.3056 \\
(0.8667)\end{array}$ & $\begin{array}{l}-0.4372 \\
\quad(-1.1874)\end{array}$ & $\begin{array}{l}0.2261 \\
\quad(0.7962)\end{array}$ & $\begin{array}{l}-0.0402 \\
\quad(-0.1553)\end{array}$ & $\begin{array}{r}-0.1179 \\
\quad(-0.4206)\end{array}$ \\
\hline $\begin{array}{l}\text { Lagged growth of "non- } \\
\text { troubled" lending }\end{array}$ & $\begin{array}{l}-0.0197 \\
\quad(-0.1034)\end{array}$ & $\begin{array}{r}-0.2663 \\
(-1.5445)\end{array}$ & $\begin{array}{l}-0.0791 \\
\quad(-0.4665)\end{array}$ & $\begin{array}{l}0.1542 \\
\quad(1.2626)\end{array}$ & $\begin{array}{l}0.1145 \\
\quad(1.0738)\end{array}$ & $\begin{array}{r}0.1815^{* *} \\
(2.2240)\end{array}$ \\
\hline Capital "surplus" & $\begin{array}{l}4.2215 \\
\quad(0.3807)\end{array}$ & $\begin{array}{l}6.4602 \\
\quad(1.2795)\end{array}$ & $\begin{array}{l}-4.3578 \\
\quad(-1.3532)\end{array}$ & $\begin{array}{r}-7.7444^{* *} \\
\quad(-2.1423)\end{array}$ & $\begin{array}{l}3.1321 \\
\quad(1.0909)\end{array}$ & $\begin{array}{l}-2.1843 \\
\quad(-1.1048)\end{array}$ \\
\hline CITY & $\begin{array}{l}-0.0077 \\
\quad(-0.0808)\end{array}$ & $\begin{array}{l}0.1721^{*} \\
(1.7695)\end{array}$ & $\begin{array}{l}-0.0536 \\
\quad(-0.5896)\end{array}$ & $\begin{array}{l}0.1603^{* *} \\
\quad(2.5738)\end{array}$ & $\begin{array}{l}-0.0897 \\
\quad(-1.1750)\end{array}$ & $\begin{array}{r}0.1121^{* *} \\
\quad(2.1058)\end{array}$ \\
\hline TRUST & $\begin{array}{l}0.0922 \\
\quad(0.4279)\end{array}$ & $\begin{array}{l}0.0529 \\
\quad(0.7081)\end{array}$ & $\begin{array}{l}-0.0226 \\
\quad(-0.2657)\end{array}$ & $\begin{array}{l}0.0247 \\
\quad(0.3886)\end{array}$ & $\begin{array}{l}-0.0290 \\
\quad(-0.3638)\end{array}$ & $\begin{array}{r}-0.0562 \\
\quad(-1.0024)\end{array}$ \\
\hline REGIONAL & $\begin{array}{l}0.0094 \\
\quad(0.3081)\end{array}$ & $\begin{array}{l}0.0307 \\
(0.9706)\end{array}$ & $\begin{array}{l}0.0171 \\
\quad(0.5512)\end{array}$ & $\begin{array}{r}0.0687^{*} \\
(1.9236)\end{array}$ & $\begin{array}{l}-0.0064 \\
\quad(-0.1974)\end{array}$ & $\begin{array}{l}0.0030 \\
(0.0850)\end{array}$ \\
\hline $\begin{array}{lr}\text { J statistics } & 48.3256 \\
(0.2326)\end{array}$ & Number of & servations & 756 & & & \\
\hline
\end{tabular}

Note: $* * *$ shows $1 \%, * *, 5 \%$, and $*, 10 \%$, respectively.

Numbers shown in parentheses below $J$ statistics are $\mathrm{p}$-value 
Table 5-4 Regression results of equation (2), "non-troubled" industries exclude the financial and insurance industry

\begin{tabular}{|c|c|c|c|c|c|c|}
\hline & 1995 & 1996 & 1997 & 1998 & 1999 & 2000 \\
\hline Constant & $\begin{array}{l}-0.0004 \\
\quad(-0.0167)\end{array}$ & $\begin{array}{l}-0.0043 \\
\quad(-0.1811)\end{array}$ & $\begin{array}{l}-0.0223 \\
\quad(-0.8831)\end{array}$ & $\begin{array}{l}-0.0295 \\
\quad(-1.2132)\end{array}$ & $\begin{array}{l}-0.0373 \\
\quad(-1.4242)\end{array}$ & $\begin{array}{r}-0.0370 \\
\quad(-1.2618)\end{array}$ \\
\hline $\begin{array}{l}\text { Lagged growth of } \\
\text { "troubled" lending }\end{array}$ & $\begin{array}{l}0.1982 \\
\quad(0.4496)\end{array}$ & $\begin{array}{l}0.6163 \\
\quad(1.5123)\end{array}$ & $\begin{array}{l}-0.1555 \\
\quad(-0.3777)\end{array}$ & $\begin{array}{l}0.2369 \\
\quad(0.7133)\end{array}$ & $\begin{aligned}-0.3788 \\
(-1.3073)\end{aligned}$ & $\begin{array}{r}-0.7806^{* *} \\
(-2.3764)\end{array}$ \\
\hline $\begin{array}{l}\text { Lagged growth of "non- } \\
\text { troubled" lending }\end{array}$ & $\begin{array}{r}-0.1152 \\
\quad(-0.6076)\end{array}$ & $\begin{array}{r}-0.3039^{*} \\
\quad(-1.7086)\end{array}$ & $\begin{array}{l}0.4228^{* * *} \\
\quad(2.6961)\end{array}$ & $\begin{array}{l}0.0220 \\
\quad(0.1362)\end{array}$ & $\begin{array}{r}0.3836^{* *} \\
(2.6874)\end{array}$ & $\begin{array}{r}0.4366^{* * *} \\
(3.5876)\end{array}$ \\
\hline Capital "surplus" & $\begin{array}{l}0.6162 \\
\quad(0.0547)\end{array}$ & $\begin{array}{l}4.1433 \\
\quad(0.6983)\end{array}$ & $\begin{array}{l}-3.4977 \\
\quad(-1.0207)\end{array}$ & $\begin{array}{l}-1.4617 \\
\quad(-0.3730)\end{array}$ & $\begin{array}{l}6.9203^{* *} \\
(2.1942)\end{array}$ & $\begin{array}{l}2.5125 \\
\quad(1.0621)\end{array}$ \\
\hline CITY & $\begin{array}{l}-0.0697 \\
(-0.6742)\end{array}$ & $\begin{array}{l}0.0822 \\
(0.7172)\end{array}$ & $\begin{array}{l}0.0945 \\
\quad(0.9696)\end{array}$ & $\begin{array}{l}0.0877 \\
(1.2710)\end{array}$ & $\begin{array}{l}-0.0193 \\
\quad(-0.2208)\end{array}$ & $\begin{array}{l}0.1470 \\
\quad(2.4376)\end{array}$ \\
\hline TRUST & $\begin{array}{l}0.0534 \\
\quad(0.2426)\end{array}$ & $\begin{array}{r}-0.0294 \\
\quad(-0.3507)\end{array}$ & $\begin{array}{r}-0.1143^{*} \\
(-1.1533)\end{array}$ & $\begin{array}{l}0.0084 \\
\quad(0.1134)\end{array}$ & $\begin{array}{r}-0.0162 \\
\quad(-0.1826)\end{array}$ & $\begin{array}{l}-0.0665 \\
\quad(-1.0370)\end{array}$ \\
\hline REGIONAL & $\begin{array}{l}-0.0416 \\
(-1.2969) \\
\end{array}$ & $\begin{array}{r}-0.0568 \\
\quad(-1.6511) \\
\end{array}$ & $\begin{array}{r}-0.0652^{*} \\
(-1.8592) \\
\end{array}$ & $\begin{array}{l}0.0173 \\
(0.4519) \\
\end{array}$ & $\begin{array}{r}-0.0192 \\
(-0.5424) \\
\end{array}$ & $\begin{array}{r}-0.0191 \\
\quad(-0.4377) \\
\end{array}$ \\
\hline $\begin{array}{ll}\text { J statistics } & \begin{array}{l}38.1291 \\
(0.6416)\end{array}\end{array}$ & 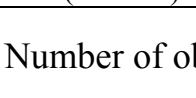 & rvations & 75 & & & \\
\hline
\end{tabular}

Note: $* * *$ shows $1 \%, * *, 5 \%$, and $*, 10 \%$, respectively and numbers shown in parentheses below $\mathrm{J}$ statistics are p-value

Table 6-1 Year by year coefficients on capital "surplus" measures for lending to non real estate related troubled industries and non-troubled non-manufacturing lending, 49 regional banks and 48 regional 2 banks

\begin{tabular}{|c|c|c|c|c|c|c|c|}
\hline Group of banks & Group of industries & 1995 & 1996 & 1997 & 1998 & 1999 & 2000 \\
\hline \multirow{3}{*}{ Regional banks } & Troubled (1) & $\begin{array}{l}2.6118 \\
\quad(1.3105)\end{array}$ & $\begin{array}{r}3.2901^{* *} \\
(2.5962)\end{array}$ & $\begin{array}{c}2.6871^{* * *} \\
\quad(3.1355)\end{array}$ & $\begin{array}{l}0.3197 \\
\quad(0.3654)\end{array}$ & $\begin{array}{r}-0.1317 \\
(-0.1940)\end{array}$ & $\begin{array}{l}1.1814 \\
\quad(1.5444)\end{array}$ \\
\hline & Non- troubled (2) & $\begin{array}{l}7.4764 \\
\quad(1.0852)\end{array}$ & $\begin{array}{l}0.9829 \\
\quad(0.2408)\end{array}$ & $\begin{array}{r}6.4116^{* *} \\
(2.4376)\end{array}$ & $\begin{array}{r}8.4511^{* * *} \\
\quad(3.2231)\end{array}$ & $\begin{array}{l}2.1911 \\
\quad(0.8809)\end{array}$ & $\begin{array}{l}3.7935 \\
\quad(1.3715)\end{array}$ \\
\hline & Non- troubled (3) & $\begin{array}{r}8.8643^{* *} \\
(2.1655)\end{array}$ & $\begin{array}{r}2.5162 \\
(0.9362)\end{array}$ & $\begin{array}{r}7.4871^{* * *} \\
(4.3593)\end{array}$ & $\begin{array}{c}0.6933 \\
(0.3627)\end{array}$ & $\begin{array}{l}0.6287 \\
\quad(0.4176)\end{array}$ & $\begin{array}{l}0.3452 \\
\quad(0.2072)\end{array}$ \\
\hline \multirow{3}{*}{ Regional 2 banks } & Troubled (1) & $\begin{array}{l}2.2091 \\
\quad(0.5063)\end{array}$ & $\begin{array}{l}-0.5911 \\
(-0.3848)\end{array}$ & $\begin{array}{l}2.7030^{* *} \\
\quad(2.3685)\end{array}$ & $\begin{array}{l}-0.7175 \\
\quad(-0.6158)\end{array}$ & $\begin{array}{l}-0.2468 \\
\quad(-0.2087)\end{array}$ & $\begin{array}{l}0.2628 \\
(0.4018)\end{array}$ \\
\hline & Non- troubled (2) & $\begin{array}{l}-0.4540 \\
\quad(-0.0372)\end{array}$ & $\begin{array}{l}1.4291 \\
(0.2908)\end{array}$ & $\begin{array}{l}1.8580 \\
\quad(0.5693)\end{array}$ & $\begin{array}{l}-0.5111 \\
(-0.1963)\end{array}$ & $\begin{array}{c}-7.1490^{* *} \\
(-2.1725)\end{array}$ & $\begin{array}{l}-0.1052 \\
(-0.0585)\end{array}$ \\
\hline & Non- troubled (3) & $\begin{array}{l}3.1815 \\
(0.2989)\end{array}$ & $\begin{array}{r}-1.6176 \\
(-0.3824)\end{array}$ & $\begin{array}{l}5.9665^{* *} \\
(2.3744)\end{array}$ & $\begin{array}{r}-1.4371 \\
(-0.6674)\end{array}$ & $\begin{array}{r}-2.5750 \\
(-0.9540)\end{array}$ & $\begin{array}{r}-2.4209 \\
\quad(-1.5821)\end{array}$ \\
\hline
\end{tabular}

Note: The financial and insurance industry is included into the "non-troubled" industries in the first row and is excluded in the second row 
Table 6-2 Aggregate lending growths to troubled and non-troubled industries

\begin{tabular}{llrrrrrr}
\hline & 1995 & 1996 & 1997 & 1998 & 1999 & 2000 \\
\hline \hline \multirow{3}{*}{ Regional banks } & Troubled (1) & 1.14 & -0.41 & -0.77 & -2.28 & -6.55 & -2.85 \\
& Non- troubled (2) & -1.77 & -4.38 & -0.91 & -2.53 & -2.11 & 1.64 \\
& Non- troubled (3) & 0.25 & 4.12 & 3.18 & -0.01 & -4.84 & -1.83 \\
\cline { 3 - 6 } Regional 2 banks & Troubled (1) & 1.40 & 0.59 & -0.89 & -1.25 & -4.25 & -1.75 \\
& Non- troubled (2) & 4.68 & 2.95 & -0.20 & 0.32 & -2.70 & -1.24 \\
& Non- troubled (3) & 4.27 & 3.51 & -0.49 & 0.35 & -1.60 & -0.26 \\
\hline
\end{tabular}

Note: The financial and insurance industry is included into the "non-troubled" industries in the first row and is excluded in the second row.

Table 6-3 Aggregate capital shocks to bank lending supply, 49 regional banks and 48 regional 2 banks

\begin{tabular}{llllllll}
\hline Group of banks & Group of industries & 1995 & 1996 & 1997 & 1998 & 1999 & 2000 \\
\hline \hline \multirow{2}{*}{ Regional banks } & Troubled (1) & -0.62 & $-0.50^{* *}$ & $-1.03^{* * *}$ & -0.09 & -0.03 & 0.93 \\
& Non- troubled (2) & -1.79 & -0.15 & $-2.45^{* *}$ & $-2.25^{* * *}$ & 0.42 & 2.97 \\
& Non- troubled (3) & $-2.12^{* *}$ & -0.38 & $-2.86^{* * *}$ & -0.18 & 0.12 & 0.26 \\
\hline & Troubled (1) & -0.14 & 0.04 & $-1.62^{* * *}$ & 0.22 & -0.07 & 0.11 \\
\multirow{2}{*}{ Regional 2 banks } & Non- troubled (2) & 0.03 & -0.09 & -1.11 & 0.16 & $-2.02^{* *}$ & -0.04 \\
& Non- troubled (3) & -0.02 & 0.01 & $-3.57^{* *}$ & 0.45 & -0.73 & -0.01 \\
\hline
\end{tabular}

Note: The financial and insurance industry is included into the "non-troubled" industries in the second row and is excluded in the third row.

Table 6-4 Year by year coefficients on capital "surplus" measures in equation (2), regional and regional 2 banks

\begin{tabular}{llcccccc}
\hline Group of banks & \multicolumn{1}{c}{ Non-troubled } & 1995 & 1996 & 1997 & 1998 & 1999 & 2000 \\
\hline \hline \multirow{5}{*}{ Regional banks } & Includes the financial & -2.8951 & 2.2041 & -3.3497 & $-10.7439^{* * *}$ & -3.5227 & -3.2139 \\
& and insurance & $(-0.3535)$ & $(0.5364)$ & $(-1.1592)$ & $(-2.7430)$ & $(-1.5178)$ & $(-1.1686)$ \\
& Excludes the financial & -6.8577 & -0.9769 & $-3.8516^{* *}$ & -0.9903 & 0.1279 & 1.1594 \\
& and insurance & $(-1.6330)$ & $(-0.3891)$ & $(-2.2573)$ & $(-0.4251)$ & $(0.0992)$ & $(0.7648)$ \\
\hline & Includes the financial & 4.3710 & -4.0779 & 1.2172 & -5.2666 & $7.3340^{* *}$ & 1.3179 \\
\multirow{2}{*}{ Regional 2 banks } & and insurance & $(0.3255)$ & $(-0.8131)$ & $(0.3382)$ & $(-1.4572)$ & $(2.1364)$ & $(0.6850)$ \\
& Excludes the financial & 4.4535 & -0.2184 & -2.5262 & 0.2135 & 3.4526 & $3.0973^{*}$ \\
& and insurance & $(0.3902)$ & $(-0.0511)$ & $(-0.8723)$ & $(0.0706)$ & $(1.2271)$ & $(1.8563)$ \\
\hline
\end{tabular}

Note: The financial and insurance industry is included into the "non-troubled" industries in the second row and is excluded in the third row. 